\begin{tabular}{|c|c|c|c|c|c|c|}
\hline \multirow{4}{*}{ Impact Factor: } & ISRA (India) & $=3.117$ & SIS (USA) & $=0.912$ & ICV (Poland) & $=6.630$ \\
\hline & ISI (Dubai, UAI & $=0.829$ & РИНЦ (Russia) & $=0.156$ & PIF (India) & $=1.940$ \\
\hline & GIF (Australia) & $=0.564$ & ESJI (KZ) & $=5.015$ & IBI (India) & $=4.260$ \\
\hline & JIF & $=1.500$ & SJIF (Morocco) & $=5.667$ & & \\
\hline
\end{tabular}

\begin{tabular}{|c|c|}
\hline $\begin{array}{l}\text { SOI: } \underline{1.1 / 7} \\
\text { International } \\
\text { Theoretical } \mathbf{\&}\end{array}$ & $\frac{\mathrm{AS}}{\text { ientific Journal }}$ \\
\hline p-ISSN: 2308-4944 (print) & e-ISSN: 2409-0085 (online) \\
\hline Year: $2018 \quad$ Issue: 12 & Volume: 68 \\
\hline Published: 17.12.2018 & tttp://T-Science.org \\
\hline
\end{tabular}

SECTION 32. Jurisprudence.
QR - Issue

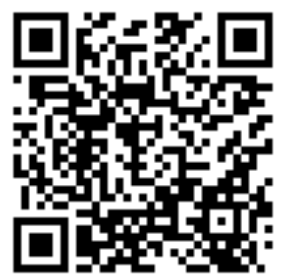

Serimzhan Tuleuovich Dossumov

Candidate of Juridical Sciences

Doctoral candidate of the Kyrgyz-Russian Slavic

University in the name of the first Russian Federation

President B.N Yeltsin

Aibek Nasyrovich Adilov

doctor of juridical sciences, professor

Head of the faculty No. 4 of Ministry of Internal Affairs of

the Kyrgyz Republic Academy

\title{
HISTORICAL ASPECTS OF FORMATION AND DEVELOPMENT OF THE SUFFRAGE IN THE REPUBLIC OF KAZAKHSTAN AND THE KYRGYZ REPUBLIC
}

Abstract: This article would make the attempt to investigate for motion and development of electoral laws of the Republic of Kazakhstan and the Kyrgyz Republic in historical and legal aspects and to show its value in creation of democracy in the explored countries, while taking in to account the considered scientific works and archived documents.

Key words: historical and legal aspects of the suffrage; electoral process; electoral system.

Language: Russian

Citation: Dossumov, S. T., \& Adilov, A. N. (2018). Historical aspects of formation and development of the suffrage in the republic of Kazakhstan and the Kyrgyz republic. ISJ Theoretical \& Applied Science, 12 (68), 70-73.

Soi: http://s-o-i.org/1.1/TAS-12-68-14 Doi: crossef https://dx.doi.org/10.15863/TAS.2018.12.68.14

\section{ИСТОРИЧЕСКИЕ АСПЕКТЫ СТАНОВЛЕНИЕ И РАЗВИТИЕ ИЗБИРАТЕЛЬНОГО ПРАВА В РЕСПУБЛИКИ КАЗАХСТАН И КЫРГЫЗСКОЙ РЕСПУБЛИКИ}

Аннотация: В данной статье делается попытка, с учетом рассмотренных научных трудов и архивных документов, исследовать в историко-правовом аспекте формирование и развитие избирательного законодательства Республики Казахстан и Кыргызской Республики и показать его значение в построении демократии в исследуемых странах.

Ключевые слова: историко-юридические аспекты избирательного права; избирательный процесс; избирательная система.

\section{Introduction}

За последнее время выбор прочно вошел в жизнь казахстанского и кыргызстанского обществ в качестве реально функционирующих институтов формирования представительной основы народовластия.

В наше время происходят становление и развитие современных избирательных систем двух демократических и независимых центрально-азиатских стран, сопровождаемый активными поисками и апробацией на практике юридической формулы осуществления и защиты конституционных права граждан избирать и быть избранными в орган государственной власти и местного самоуправления.

Процессы формирования избирательного законодательства охватили практически все уровни правового регулирования, в которых включен не только законодательная ветвь власти, но и президентская и правительственная структуры.

В Казахстане и Кыргызстане проводятся полномасштабные политические реформы, направленные на развитие демократического начала в формировании и деятельности института 


\begin{tabular}{|c|c|c|c|c|c|c|}
\hline \multirow{4}{*}{ Impact Factor: } & ISRA (India) & $=3.117$ & SIS (USA) & $=0.912$ & ICV (Poland) & $=6.630$ \\
\hline & ISI (Dubai, UAE & $=0.829$ & РИНЦ (Russia) & $=0.156$ & PIF (India) & $=1.940$ \\
\hline & GIF (Australia) & $=0.564$ & ESJI (KZ) & $=\mathbf{5 . 0 1 5}$ & IBI (India) & $=4.260$ \\
\hline & JIF & $=1.500$ & SJIF (Morocco) & $=5.667$ & & \\
\hline
\end{tabular}

государственной власти и местного самоуправления. Органическими составляющими этих реформ являются реформы избирательной системы, обеспечивающие демократические воспроизводства и ротации власти по итогам периодически проводимого выбора.

В этой связи, первостепенное значение в процессах трансформации института публичной власти приобретает исследование действующего избирательного права и законодательств.

Надо сказать, что институтам выборов, как в советский время, так и в современный, всегда придавались исключительно необходимое политическое место.

Поэтому, полагаем важным вспомнить историю становления избирательного права, для уяснения реалии сегодняшнего времени. По мнению авторов необходимо определить историческое развитие институтов выборов на протяжении тысячелетия как многогранного явления. Они включают исследования развития процедур выборов, развития круга участников выборов и анализа избирательного документа.

В связи с этим, в данной работе делаются попытки, с учетом рассмотренного научного труда и архивного документа, провести исследования в историко-правовых аспектах формирования и развития избирательного законодательства Республики Казахстан и Кыргызской Республики и установить их значение в становлении демократии в исследуемых государствах.

Историко-юридические аспекты исследования базируются на изучении исторического документа, акта и сборника законов, а также монографического исследования, в связи с чем, в современном научным исследовании вопрос формирования и развития избирательных законодательств Республики Казахстан и Кыргызской Республики как самостоятельных тем диссертационного исследования проводятся впервые.

\section{Materials and Methods}

Исторические аспекты института выборов представляют интерес для историков и государствоведов всегда. Однако довольно длительное время исследование советской историко-правовой науки выборов и избирательного права находилось под влияниями общих партийно-политических установок: все важные достижения государственно-правовых сфер признавалось исключительно завоеванием советской власти. Вследствие чего, выборы, в случае признания, объявляись под установленным углом зрения - подчеркивались их несовершенства, внимания акцентировались на классовые противоречия между их участниками. Необходимо отметить, что институты выборов в советском обществе развивались благодаря многовековой исторической традиции, предпочтение отдавалось созданию впечатлений, что выборы в советское время не отличались от дореволюционного и появились буквально на пустом [9]. Данные подходы вполне объяснимы, ведь если провести непредвзятые сравнения между выборностью определенных дореволюционного института и советскими выборами, то советские системы проиграли бы. Этим же соображением объясняется то, что определенные категории института, такие, например, как мажоритарные избирательные системы, применялась лишь в отношении дореволюционного и зарубежного выборов. Советские государствоведы часто выполняли политические заказы, критиковали недостатки мажоритарных систем зарубежных или дореволюционных выборов, но умалчание о том, что именно они, какими бы завесами их не маскировали, господствовала и в советской стране. Наличие единственных кандидатов на выборные посты придавало советским «самым демократическим» выборам характер фикции, имеющей только идеологические значения, а исследования института заключались в восхвалении совершенств советских выборов. В указанных условиях реальные исследования, свободные от идеологических и политических прессингов и, тем более, признающие вероятности преемственности в станволении института, было невозможным [1, с.3].

Некоторые исследования,

кроме хронологической, имеют ограниченную территориальную рамку. В них они изучаются с различной степенью конкретизации как часть государственно-правовых практик той или иной местности в определенный отрезок времени.

Исследование электоральных наследий Казахстана и Кыргызстана представляют интерес и как часть общей истории наших государств, и выступает важным элементом характеристики современного состояния соответствующих правовых институтов. Знание основной тенденции становления избирательных систем способствуют адекватному восприятию современных избирательных систем и электоральной практики, позволяют правильно направить реформу в соответствующих областях отношений и в определенных мерах прогнозировать тенденцию его развития [2].

Относительно избирательной системы в исторических ретроспективах, необходимо подчеркнуть, что в современных понятиях избирательной системы, вплоть до начала XX в., как в Казахстане, так и в Кыргызстане не существовали, поскольку не были учеты точного количества голосовавших и особых порядков 


\begin{tabular}{|c|c|c|c|c|c|c|}
\hline \multirow{4}{*}{ Impact Factor: } & ISRA (India) & $=3.117$ & SIS (USA) & $=0.912$ & ICV (Poland) & $=6.630$ \\
\hline & ISI (Dubai, UAI & $=0.829$ & РИНЦ (Russia) & $=0.156$ & PIF (India) & $=1.940$ \\
\hline & GIF (Australia) & $=0.564$ & ESJI (KZ) & $=5.015$ & IBI (India) & $=4.260$ \\
\hline & JIF & $=1.500$ & SJIF (Morocco) & $=5.667$ & & \\
\hline
\end{tabular}

голосования на собрании. В указанное время они была представлены в политико-правовом становлении наших стран в качестве институтов выборности.

На территории будущего Казахстана и Кыргызстана уже в сакских протогосударственных объединениях в условиях военной демократии избирался вождь племени и для участников племенного собрания существовал даже определенные условия [7].

Казахи и кыргызы принадлежат к числу древнейших народов Средней Азии. Из народов живущих в Средней Азии в настоящее время, нет, по-видимому, ни одного, название которого так рано встречалось бы в истории.

Вследствие широкого обмена мнением между крупнейшими учеными разных профилей АН СССР, АН Казахской ССР, АН Киргизской ССР и научными учреждениями других братских республик на всесоюзной научной конференции по этногенезу (происхождению) кыргызского народа, проходившей в 1956 г. во Фрунзе (ныне Бишкек) были сделаны заключения: «Кыргызский народ и его культура сложились... в результате взаимодействия, по меньшей мере, двух этнических элементов: центральноазиатского и местного - среднеазиатского. Один из важнейших «узловых» моментов этногенеза кыргызского народа, ближайший по времени, связан с событиями первой половины второго тысячелетия нашей эры. В эту эпоху на территорию Киргизии проникает с Востока значительное большинство предков современных кыргызов, говоривших уже на сложившемся кыргызском языке... Кыргызы становятся численно преобладающей группой населения на территории Киргизии, чего ни в коем случае нельзя сказать по отношению к более ранним эпохам» [3].

Становлением государственности и централизацией политической власти существовавшие системы выборности постепенно исчезают или трансформируются. На смену военно-демократическим голосованиям приходят назначения на должности, исходя из соображений личных преданностей или родственного отношения претендента. С установлением монархического правления взамен выборности вождя используются династические передачи власти по наследству. Например, в тюркском племенном объединении власть наследовалась членом аристократического рода ашина, а в монгольской империи представителем наследственных линий Чингисхана. Именно принципы происхождений стали главными при избрании и утверждении хана на народных собраниях, а позднее и при передачах верховной власти в Казахском ханстве [8].
До сегодняшнего дня нет крупных научных работ, которые рассматривали бы вопрос избирательного права. Многие исторические работы о кочевых и полуоседлых народах Средней Азии, в том числе о казахах и кыргызах, концентрируют свое внимание на общие описания быта, формальные сводки по родовым номенклатурам, государственной, либо внутриплеменной структуры (общественной системы самоуправления), проблеме этногенеза, материальной культуры, а также на вопросе брачно-семейного отношения.

История кыргызов официально берет начало с первой половины XVI в., когда на территории Тянь-Шаня (сегодняшней территории Кыргызстана) вследствие ассимиляции енисейских кыргызов, образовывается нацияк кыргызов в современном облике [6, с. 208-218].

Следует отметить, что избирательное право кыргызов и казахов берут свое начало с момента их родовых устройств. Родовая община представляет собой по сущности и формам самоуправляющийся элемент, который формировался самим народом. Объединения кыргызов и казахов в родовые общины были обусловлены экономическим интересом и стремлениями, организовать общины от нападения неприятелей.

Таким образом, особенностью образа правления казахов и кыргызов было то, что преобладала избирательно-представительная система, с обязательным элементом наследственного.

Дооктябрьской революционый период Средняя Азия и Казахстан были разделены на произвольно сформированные, без учета национальных составов населений, областей. В следующие несколько десятилетия народом управлял царская администрация и феодальнобайская верхушка, руководствовались при этом эклектическими смесями старого царского закона, шариата и нормами обычного права. В октябре 1917 г. было положено начало новой эпохе становление кыргызской государственности. Раздробленные территории Кыргызстана входили в виде уезда в разную область Туркестанской Автономной Советской Социалистической Республики [3].

Декларацией прав народов России в 1917 г. провозглашено право на самоопределение для каждой нации. Конкретные условия, в том числе географические положения, международные окружения, уровни национального самосознания и прочее, обусловил разное условие для реализации этих прав.

С 1918г. по 1920г. национальногосударственные устройства определялись процессами вхождения автономной республики и автономной области в состав РСФСР и 


\begin{tabular}{|c|c|c|c|c|c|c|}
\hline \multirow{4}{*}{ Impact Factor: } & ISRA (India) & $=3.117$ & SIS (USA) & $=0.912$ & ICV (Poland) & $=6.630$ \\
\hline & ISI (Dubai, UAE & $=0.829$ & РИНЦ (Russia) & $=0.156$ & PIF (India) & $=1.940$ \\
\hline & GIF (Australia) & $=0.564$ & ESJI (KZ) & $=\mathbf{5 . 0 1 5}$ & IBI (India) & $=4.260$ \\
\hline & JIF & $=1.500$ & SJIF (Morocco) & $=5.667$ & & \\
\hline
\end{tabular}

заключениями двустороннего договора между независимыми странами РСФСР. Самой крупной автономной республикой стала Туркестанская, образованная в начале 1918 г., в Средней Азии.

Нужно согласиться с Автандиловой С.М. в том, что Конституция Туркестанской АССР (1918 г.) включала норму об избирательных правах граждан, основанные на начале полного равенства голосов избирателя независимо от их социальных принадлежностей. Именно в норме избирательного права наиболее зримо проявляются социальная направленность установленные в том или ином государстве власти. Анализируя содержания избирательных прав граждан, определенных Конституциями ТАССР 1918 и 1920 годов, указано, что безусловными достоинствами новых избирательных систем стали отмены ценза пола, имущественных цензов, а также существенные снижения возрастного ценза - до 18 лет. Конституция допускала также местному Совету с утверждением центральной власти снижать эти возрастные нормы [4].

После присоединения к России и вплоть до 1936 г. избирательные системы Казахстана и Кыргызстана основывались сначала на соответствующем законодательстве царской России, а после Октябрьской революции - на законодательстве СССР.

\section{Conclusion}

C включением Казахстана и позднее Кыргызстана в состав Российского государства произошли совмещения традиционного потестарного и нового государственного института. Долгий период они существовали, дополняя друг друга и выполняя разные функции [10].

Однако постепенно, в силу разных причин, но в значительной степени из-за политики царской власти, эти структурные элементы социально-политической организации стали налагаться друг на друга. По различным причинам постепенно происходил подрыв авторитета традиционных управленческих структур и их замещение институциональными. Все это привело к расширению сферы действия государственных органов. В середине XIX в. Российским правительством принимается окончательное решение о ликвидации ханской власти и передаче их полномочий иным административным органам. Все это подготовило почву унификации системы управления в рамках единого имперского пространства путем упразднения нетипичных должностей и званий [5, c. 146].

\section{References:}

1. Minnikes, I. V. (2010). Vyiboryi $v$ istorii Rossiyskogo gosudarstva v IX - nachale XIX veka. (p.3). Izd-vo «Yuridicheskiy tsentr Press»».

2. Volgina, A. P. (2008). Stanovlenie izbiratelnyih sistem v Respublike Kazahstan i Rossiyskoy Federatsii (Istoricheskiy aspekt). Vestnik $K A R G U$.

3. Dzhumabaev, M. D. (2004). Razvitie izbiratelnoy sistemyi Kyirgyizskoy Respubliki. Avtoref. diss. k.yu.n. - M..

4. Avtandilova, S. M. (2011). Formirovanie $i$ razvitie izbiratelnogo zakonodatelstva Kyirgyizskoy Respubliki (istoriko-pravovoe issledovanie). Avtoref. diss. k.yu.n. - B..

5. Byikov, Y. A. (2006). Hanskaya vlast u kazahov: zvaniya i/ili dolzhnost. Etnograficheskoe obozrenie, \# 3, 146.
6. Moldosheva, D. A. (2002). Aktulnyie problemyi formirovaniya $i$ povyisheniya kvalifikatsii kadrov izbiratelnyih komissiy. NAN Kyirgyizskoy Respubliki. Institut filosofii i prava. (pp.208-218) "Sovremennost: filosofskie i pravovyie problemyi". Bishkek.

7. Imanbaev, S. (1998). Reformirovanie izbiratelnoy sistemyi Kyirgyizskoy Respubliki. Byulleten Tsentralnoy komissii po vyiboram $i$ provedeniyu referendumov Kyirgyizskoy Respubliki. B., \# 4 (21), 8.

8. Zagryazhskiy, G. S. (1876). "Yuridicheskie obyichai kirgiz". Material dlya statey Turkestanskogo kraya, SPb., vyip. IV, 100-106.

9. Budyanskiy, D. (1958, March 16). Iz proshlogo. "Komsomolets Kirgizii".

10. Kovalevskiy, M. M. (1980). Sovremennyiy obyichay i drevniy zakon. (pp.4-22). M., t. I. 